\title{
A Study on Survival and Growth of Ark shell, Scapharca broughtonii with differential density during hanging culture
}

\author{
오봉세, 진영국 ${ }^{1}$ 정춘구 ${ }^{2}$, 임월애 ${ }^{2}$, 김숙양 ${ }^{2}$ \\ 동해수산연구소, ${ }^{1}$ 남서해수산연구소, ${ }^{2}$ 국립수산과학원

\begin{abstract}
A Study on Survival and Growth of Ark shell, Scapharca broughtonii with differential density on hanging culture
\end{abstract}

\author{
Bong-Se Oh, Young-Guk Jin', Choon-Goo Jung², Weol-Ae Lim² and Sook-Yang Kim² \\ East Sea Fisheries Research Institute, Gangneung 556-000, Korea \\ ${ }^{1}$ Southwest Sea Fisheries Research Institute, Yeosu 556-823, Korea \\ ${ }^{2}$ National Fisheries Research and Development Institute, Busan 610-900, Korea
}

\begin{abstract}
Ark shell Scapharca broughtonii length and total weight growth by density, which was hanging-cultured near the sea area of Yeosu-city, Hoenggan-island (below is Yeosu), showed inverse correlation with density. As for the average growth of shell length by density, the test area of 10 shells showed the best result as $5.21 \mathrm{~mm}$, and it became lower as density became higher. Also, the increase of total weight by density showed the same result, thus on the whole, the increase of average shell length and total weight of 10-20 shell test area showed the better result than the test area of 30-40 shells. In addition, even if the parashell's shell length by density and total weight growth in the sea area of Namhae-gun, Mijo-fishing port (below is Namhae) showed inverse correlation with density, it showed the slighter inverse correlation than the sea area of Yeosu. As for the average growth of shell length by density, the test area of 10 shells showed the best result as $4.55 \mathrm{~mm}$, but the average growth of shell length by density in the test area of 20-40 shells appeared to be similar as $3.11,3.36$ and $3.27 \mathrm{~mm}$. On the other hand, as for the increase of total weight by density, the test area of 10-20 shells showed the more increase than the test area of 30-40 shells. In conclusion, it is guessed that the culture density of 20 shells $/ 0.12 \mathrm{~m}^{2}$ (166 shells / $1 \mathrm{~m}^{2}$ ) would be appropriate when hanging-culturing the shells. At the sea area of A, the survival rate of Scapharca broughtonii parashell was $68-87 \%$ by density respectively, and it showed the density-dependent result, while the survival rate of sea area of Namhae, where phytoplankton as prey is abundant, showed the much better result as $91-100 \%$. It is guessed that this may be due to the fact that the quantity of phytoplankton in sea area of Yeosu is just $55.89 \%$ of sea area of Namhae. When hanging-culturing the shells, the water temperature by sea area ranged from 16.22 to $25.66^{\circ} \mathrm{C}$, salinity $30.07-33.48, \mathrm{pH} 8.10-8.45$, and DO $4.49-9.65 \mathrm{mg} / \mathrm{L}$.
\end{abstract}

Keywords: Ark shell, Scapharca broughtonii, Survival and growing rate with density

Received: March 4, 2014; Revised: March 20, 2014; Accepted: March 25, 2014

Corresponding author: Oh, Bong Se

Tel: +82 (54) 782-5497 e-mail: obsksy05@korea.kr

$1225-3480 / 24510$

This is an Open Access article distributed under the terms of the Creative Commons Attribution Non-Commercial License with permits unrestricted non-commercial use, distribution, and reproducibility in any medium, provided the original work is properly cited.

\section{서 론}

피조개 (Scapharca broughtonii) 는 부족강 (이매패강, BIVALVIA), 익형목 (PTERIOMORPHIA), 꼬막조개과 (Arcidae) 에 속하며 이 과에는 총 10 종이 보고되고 있다 (Lee and Min, 2002). 정부에서 발간하는 수산통계연감 자료 에 의하면 피조개 양식 생산량은 1975 년에 450 톤을 생산한 이후 1986 년에 58,393 톤으로 가장 많이 생산되어 일본 수출 액이 1 억 5 천만불에 이르러 수산물 단일품종으로는 굴을 능가 
A Study on Survival and Growth of Ark shell, Scapharca broughtonii with differential density during hanging culture

하는 최고의 수출품종이었다. 그러나 그 이후 매년 생산량이 감소하면서 2011년에는 2,110톤을 생산하여 1986년 대비 $3.6 \%$ 의 수준에 불과하게 되었다 (농림수산식품부, 2012). 이 런 생산감소의 원인은 어장환경의 악화로 생존율이 $1-5 \%$ 수준 으로 급감하여 피조개 양식이 황폐화 되었기 때문이다. 피조개 생존율의 급감은 여름철 고수온 및 저 비중이 원인으로 밝혀졌 다 (국립수산과학원, 2012). 피조개 양식장 바닥에 살포하여 양식하는 피조개 살포식 양식에 있어 고수온과 이로 인한 저산 소 및 저비중을 극복하는 양식법으로 수하식 양식에 관하여는 Choi et al., (2000), Kim et al., (1982), Kim (1983), Yoo and Park (1978) 등의 연구가 있는데, 본 연구에서는 여름철 의 고수온 및 저비중을 극복하기 위한 수하양성시 적합한 피조 개 사육밀도를 구명하고자 남해안의 여수 및 남해 해역에서 밀 도별 수하양성 피조개의 성장과 생존율 실험을 수행하였다. 한 편, 피조개와 패류의 밀도에 관한 연구는 Song et al., (2002) 의 큰이랑피조개의 양성밀도, Duggan, (1973) 의 해만가리비 의 양성밀도, Parsons and Dadswell (1992) 의 자이언트가 리비의 양성밀도, Oh et al., (2000) 의 해만가리비 수하양성 밀도 연구 등의 결과를 연구에 참고하였다,

\section{재료 및 방법}

피조개 수하양성 밀도 실험은 Fig. 1과 같이 2010년 4월부 터 10월까지 여수시 돌산읍 횡간도 어항 부근에 위치한 해역 (이하 여수해역) 과 남해군 미조면 미조항 앞 해상의 우렁쉥이 수하양식장 (이하 남해해역) 에서 표층 (수심 $2 \mathrm{~m}$ ) 에 진주양 성용 채롱 $(35 \mathrm{~cm}(\mathrm{~W}) \times 35 \mathrm{~cm}(\mathrm{~B}) \times 20 \mathrm{~cm}(\mathrm{H}))$ 을 설치하 고 각 채롱 당 평균 각장 $56.52-58.69 \mathrm{~mm}$, 평균 전중량 $53.16-59.65 \mathrm{~g}$ 의 피조개를 $10,20,30,40$ 마리 / $0.12 \mathrm{~m}^{2}$ 씩 수용하여 밀도별 반복 시험구 (이하 10 마리구, 20 마리구, 30 마리구, 40 마리구) 를 조성하여 성장 및 생존률을 조사하였다. 성장률 계산식은 아래와 같다.

Daily growth rate $=100 \times \operatorname{In}\left(\mathrm{L}_{1}-\mathrm{L}_{0}\right) / \mathrm{T}$,

there were $\mathrm{L}_{1}$; final mean total weight (shell length), $\mathrm{L}_{0}$; initial mean total weight (shell length), T; rearing days.

양성시험 기간 중 환경조사는 매월 1 회 성장 및 생존율조사 와 병행하였다. 수온, $\mathrm{DO}, \mathrm{pH}$, 염분은 수질측정기 (모델명: YSI-1200) 으로 현장에서 바로 측정하였고, 피조개 먹이가 되 는 식물성 플랑크톤의 양과 종류는 월 1 회 수하 양성장에서 수 심 $2 \mathrm{~m}$ 층의 해수 $1 \mathrm{~L}$ 를 수직 채수하여 루골액으로 고정하여 실험실로 옮긴 후 여과하여 분류하였다.

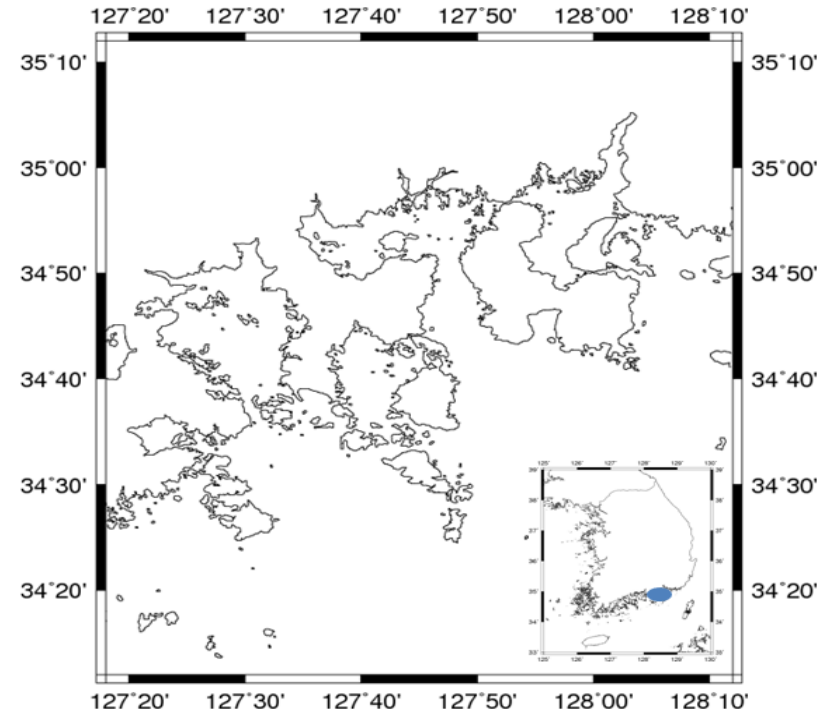

Fig. 1. The map showed rearing grounds of Ark shell, Scapharca broughtonii.

\section{결 과}

\section{1. 여수 해역의 피조개 밀도별 성장 \\ 1) 밀도별 각장 및 전중량}

4 월 여수해역에 수하양성하여 10 월에 조사한 피조개의 밀도 별 평균각장은 10 마리구는 $57.47 \mathrm{~mm}$ 에서 $62.68 \mathrm{~mm}$ 로, 20 마리구는 $56.52 \mathrm{~mm}$ 에서 $60.78 \mathrm{~mm}, 30$ 마리구는 $58.63 \mathrm{~mm}$ 에서 $60.00 \mathrm{~mm}, 40$ 마리구는 $58.27 \mathrm{~mm}$ 에서 $60.83 \mathrm{~mm}$ 로 성장하였다. 각 밀도별 사육기간 중 평균각장의 증가는 10 마리 구 $5.21 \mathrm{~mm}, 20$ 마리구 $4.26 \mathrm{~mm}, 30$ 마리구 $1.37 \mathrm{~mm}, 40$ 마 리구 $2.56 \mathrm{~mm}$ 였다 (Fig. 2). 그리고 사육기간 중 평균각장의 일간성장률을 보면 10 마리구 $1.83 \pm 1.77,20$ 마리구 $1.53 \pm$ $0.98,30$ 마리구 $0.54 \pm 0.38,40$ 마리구 $1.04 \pm 1.04$ 였다 (Fig. 4).

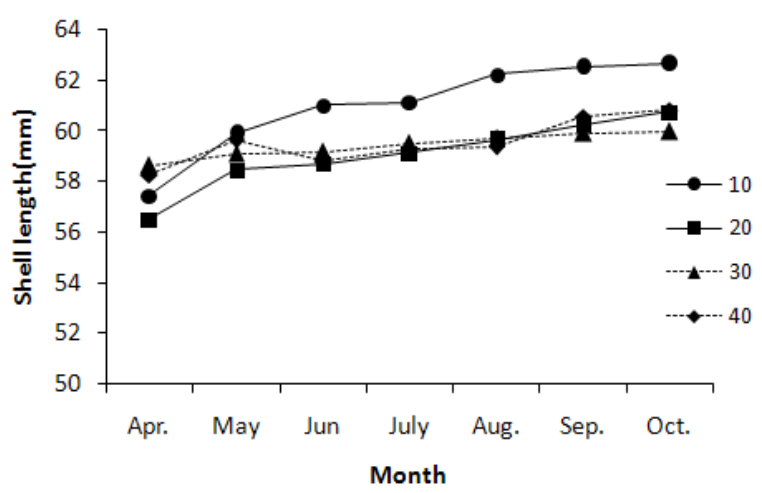

Fig. 2. The monthly growth of shell length of Scapharca broughtonii at Yeosu area. 


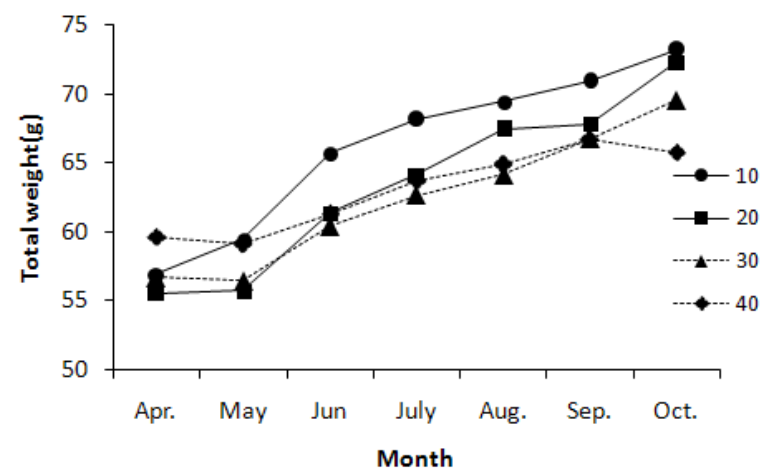

Fig. 3. The monthly growth of total weight of Scapharca broughtonii at Yeosu area.

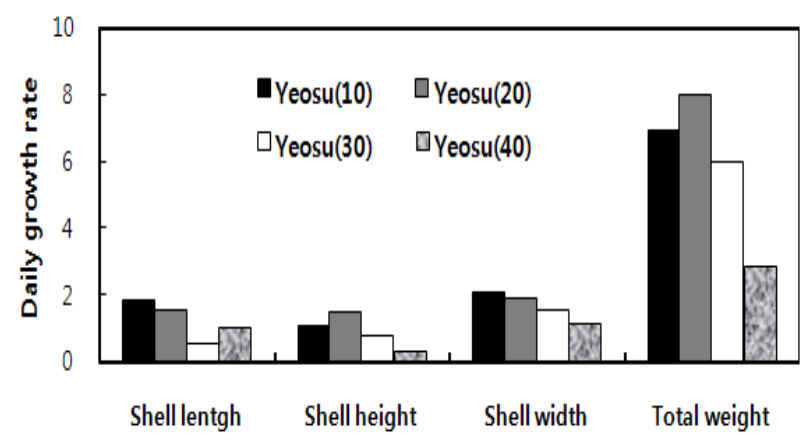

Fig. 4. Daily growth rates of shell length and total weight of Scapharca broughtonii at Yeosu area.

한편, 평균 전중량은 10 마리구는 $56.92 \mathrm{~g}$ 에서 $73.27 \mathrm{~g}$ 으로, 20 마리구는 $55.59 \mathrm{~g}$ 에서 $72.38 \mathrm{~g}, 30$ 마리구는 $56.70 \mathrm{~g}$ 에서 $69.61 \mathrm{~g}, 40$ 마리구는 $59.65 \mathrm{~g}$ 에서 $65.80 \mathrm{~g}$ 으로 증가하였다. 각 밀도별 사육기간 중 평균전중량의 증가는 10 마리구 16.35 $\mathrm{g}, 20$ 마리구 $16.79 \mathrm{~g}, 30$ 마리구 $12.91 \mathrm{~g}, 40$ 마리구 $6.15 \mathrm{~g}$ 이 였다 (fig. 3). 그리고 사육기간 중 평균 전중량의 일간성장률 을 보면 10마리구 $6.91 \pm 5.90,20$ 마리구 $8.01 \pm 7.46,30$ 마 리구 $5.99 \pm 4.73,40$ 마리구 $2.87 \pm 4.45$ 였다 (Fig. 4).

\section{2) 밀도별 생존율}

4 월부터 수하양성 실험이 종료된 10월까지 밀도별 생존율을 보면 10 마리구 $76 \%, 20$ 마리구 $76 \%, 30$ 마리구 $87 \%, 40$ 마리 구 $68 \%$ 의 생존율을 보였다 (Fig. 4).

\section{2. 남해 해역의 피조개 밀도별 성장 \\ 1) 밀도별 각장 및 전중량}

4 월 남해해역에 수하양성하여 10 월에 조사한 피조개의 밀도 별 평균각장은 10 마리구는 $58.43 \mathrm{~mm}$ 에서 $62.98 \mathrm{~mm}$ 로, 20 마리구는 $58.69 \mathrm{~mm}$ 에서 $61.80 \mathrm{~mm}, 30$ 마리구는 $57.60 \mathrm{~mm}$

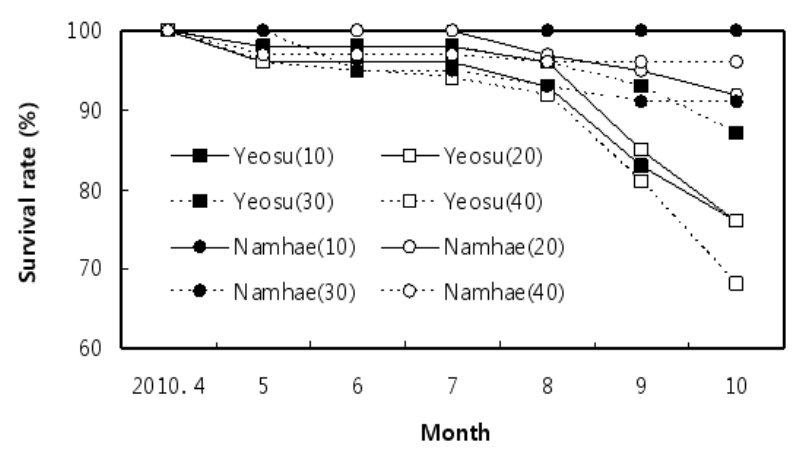

Fig. 5. The survival rate of Scapharca broughtonii during differential density rearing experiments by areas.

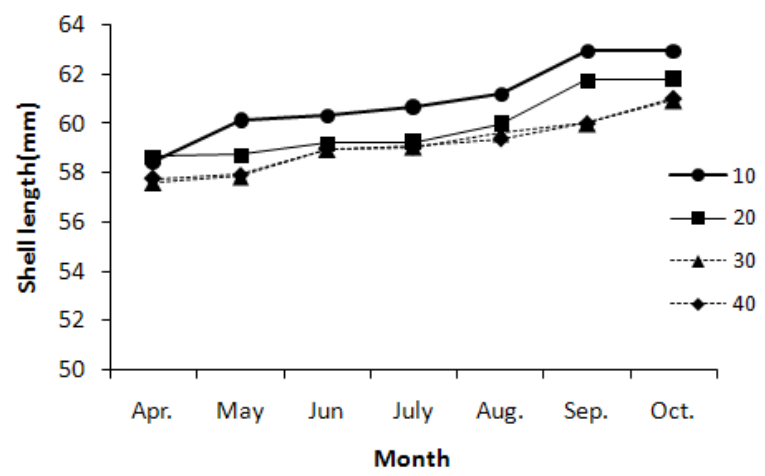

Fig. 6. The monthly growth of shell length of Scapharca broughtonii at Namhae area.

에서 $60.96 \mathrm{~mm}, 40$ 마리구는 $57.76 \mathrm{~mm}$ 에서 $61.03 \mathrm{~mm}$ 로 성장하였다. 각 밀도별 사육기간 중 평균각장의 증가는 10 마리 구 $4.55 \mathrm{~mm}, 20$ 마리구 $3.11 \mathrm{~mm}, 30$ 마리구 $3.36 \mathrm{~mm}, 40$ 마 리구 $3.27 \mathrm{~mm}$ 였다 (Fig. 6). 그리고 사육기간 중 평균각장의 일간성장률을 보면 10 마리구 $1.80 \pm 1.93,20$ 마리구 $1.35 \pm$ $1.88,30$ 마리구 $1.56 \pm 1.44,40$ 마리구 $1.50 \pm 1.47$ 였다 (Fig. 8).

한편, 평균 전중량은 10 마리구는 $58.43 \mathrm{~g}$ 에서 $74.98 \mathrm{~g}$ 으로, 20 마리구는 $57.87 \mathrm{~g}$ 에서 $75.20 \mathrm{~g}, 30$ 마리구는 $53.16 \mathrm{~g}$ 에서 $68.99 \mathrm{~g}, 40$ 마리구는 $53.47 \mathrm{~g}$ 에서 $68.98 \mathrm{~g}$ 으로 증가하였다. 각 밀도별 사육기간 중 평균전중량의 증가는 10 마리구 16.55 $\mathrm{g}, 20$ 마리구 $17.33 \mathrm{~g}, 30$ 마리구 $15.83 \mathrm{~g}, 40$ 마리구 $15.51 \mathrm{~g}$ 이였다 (Fig. 7). 그리고 사육기간 중 평균 전중량의 일간성장 률을 보면 10 마리구 $7.45 \pm 4.75,20$ 마리구 $7.90 \pm 5.36,30$ 마리구 $7.01 \pm 4.78,40$ 마리구 $6.80 \pm 5.19$ 였다 (Fig. 8).

\section{2) 밀도별 생존율}

4 월에서 수하양성 실험이 종료된 10 월까지 밀도별 생존율을 보면 10 마리구는 $100 \%, 20$ 마리구 $92 \%, 30$ 마리구 $91 \%, 40$ 
A Study on Survival and Growth of Ark shell, Scapharca broughtonii with differential density during hanging culture

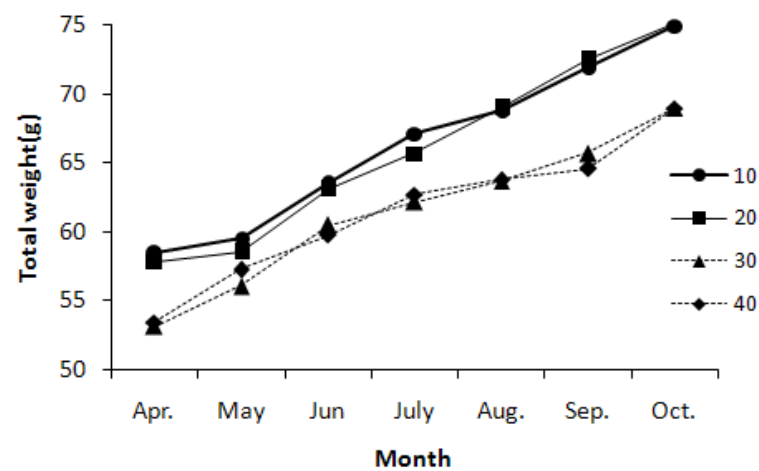

Fig. 7. The monthly growth of total weight of Scapharca broughtonii at Namhae area.

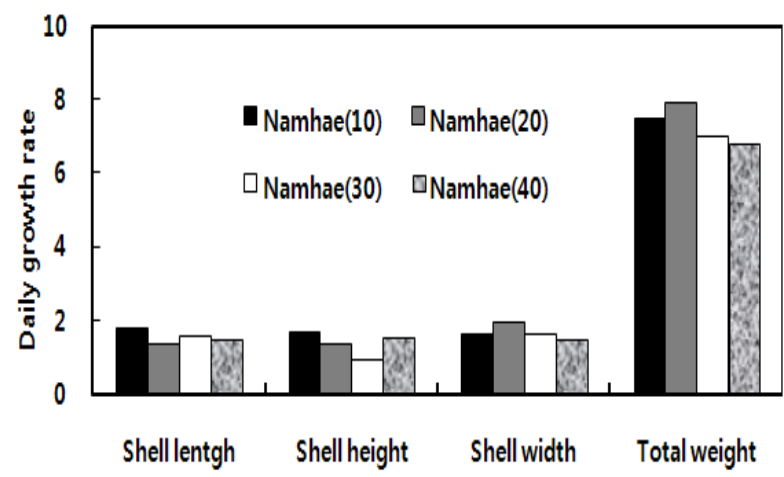

Fig. 8. Daily growth rates of shell length and total weight of Scapharca broughtonii at Namhae area.

마리구 $96 \%$ 의 생존율을 보였다 (Fig. 4)

\section{3. 플랑크톤의 출현량 및 종류}

\section{1) 여수해역의 플랑크톤 종류 및 출현량}

Fig. 9와 Fig. 11과 같이 여수해역에서 5월부터 10 월까지 먹이생물인 식물성플랑크톤의 출현종수는 Skeletonema costatum 를 비롯한 총 49종이 출현하였으며 (미동정소형편 모조류 Flagellates와 Ciliates 2종 포함), 출현량은 총 1273.75 개체/cc 이었다. 100 개체/cc 이상 출현한 식물플랑크 톤 종별 출현율을 보면 Skeletonema costatum 333.5개체/cc $(26.18 \%)$ 를 점하여 우점종으로 나타났다. 그다음은 Chaetoceros curvisetum 13.68\%, Pseudo-nitzschia spp. $12.10 \%$, Chaetoceros spp. 8.32\%, Chaetoceros costatus $7.90 \%$ 의 순이었고 미동정 소형편모조류 2 종 $8.77 \%$ 를 포함한 기타 종의 비율은 $31.80 \%$ 였다 (Fig, 10). 월별 출현종수를 보 면 7월에 28 종으로 가장 많이 출현했고 그다음은 5 월 24 종, 8 월 22 종, 9 월 13 종, 10 월 12 종, 6 월 9 종의 순이었고, 월별 출

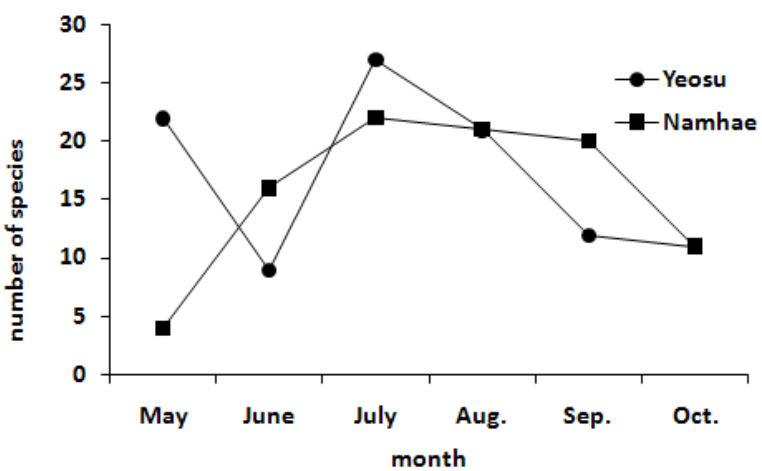

Fig. 9. Number of species of phytoplankton at Yeosu and Namhae areas.

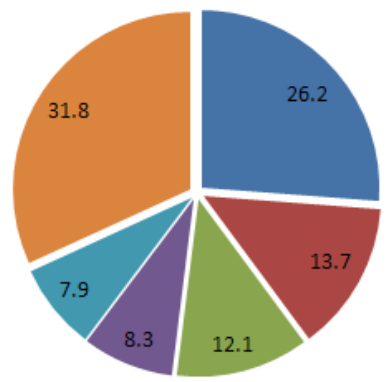

- Skeletonema costatum

- Chaetoceros curvisetum

- Pseudo-nitzschia spp.

- Chaetoceros spp.

- Chaetoceros costatus

a The others

Fig. 10. Ratio of dominant species over 100 numbers per 1 $\mathrm{ml}$ at Yeosu area.

현량은 8월에 735 개체로 가장 많았고, 7 월 353 개체, 10 월 88.75 개체, 5 월 64.5 개체, 10 월 17.5 개체, 6 월 15 개체로 가장 적게 나타났다 (Fig. 11).

\section{2) 남해해역의 플랑크톤 종류 및 출현량}

Fig. 9와 Fig. 11과 같이 남해 미조해역에서 5월부터 10 월 까지 먹이생물인 식물성플랑크톤의 출현종수은 (미동정소형편 모조류 Flagellates와 Ciliates 2종 포함) Chaetoceros curvisetum를 포함하여 총 50 종이 출현하였으며, 출현량은 총 $2,278.75$ 개체/ $1 \mathrm{cc}$ 이었다. 100 개체/ $1 \mathrm{cc}$ 이상 출현한 식물 성플랑크톤의 종별 출현율을 보면 Chaetoceros curvisetum 이 596.25 개체/ $1 \mathrm{cc}(26.16 \%)$ 를 점하여 우점종으로 나타났다. 그다음은 Pseudo-nitzschia spp. 17.99\%, Chaetoceros spp. $12.17 \%$, Skeletonema costatum $11.79 \%$ 의 순이었고 미동정 소형편모조류 2종 $2.85 \%$ 를 포함한 기타 종의 비율은 $31.88 \%$ 였다 (Fig. 12). 월별 출현종수을 보면 7월과 9월에 22 종으로 가장 많았고, 그 다음은 8월 21 종, 6 월 16 종, 10 월 12 종, 5 월 


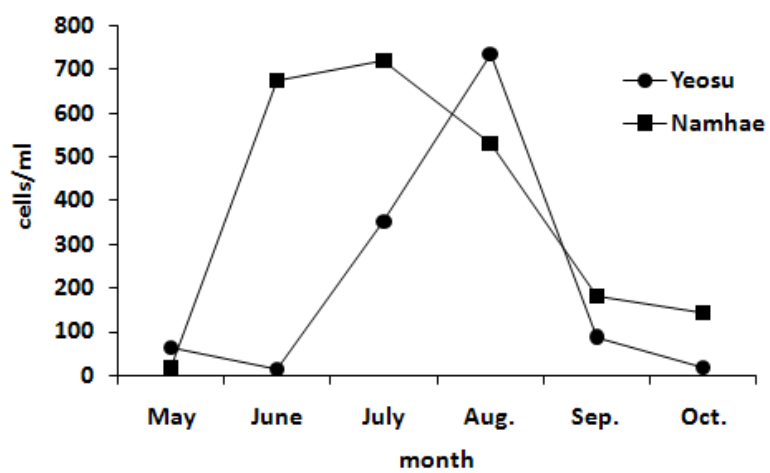

Fig. 11. Total amount of phytoplankton at Yeosu and Namhae areas.

5 종이었고, 월별 출현량은 7 월에 722.5 개체 $1 \mathrm{cc}$ 로 전체의 $31.71 \%$ 를 차지하여 가장 많았고, 6 월 $29.68 \%, 8$ 월 $23.42 \%$, 9월 $8.01 \%, 10$ 월 $6.31 \%, 6$ 월 $0.88 \%$ 의 순이었다 (Fig. 11).

\section{4. 양성시험 해역별 환경}

밀도별 성장 시험를 실시한 해역의 5 월부터 10 월까지 환경 을 보면, 여수해역은 수온 16.22-23.85 (평균 20.27) ${ }^{\circ} \mathrm{C}$ 였고, 염분은 31.80-33.48 (평균 32.62) 였으며, $\mathrm{pH}$ 는 8.13-8.39 (평균 8.21) 범위였다. 그리고 용존산소 (DO) 는 4.49-9.5610.07 (평균 7.78) $\mathrm{mg} / \mathrm{L}$ 였다. 남해해역은 수온 16.71-25.66 (평균 20.79) ${ }^{\circ} \mathrm{C}$ 엿고, 염분은 30.07-32.99 (평균 31.47 ) 였으며, $\mathrm{pH}$ 는 8.10-8.45 (평균 8.32)이었다. 그리고 용존산소 (DO) 는 4.52-9.65 (평균 8.13 ) $\mathrm{mg} / \mathrm{L}$ 를 보였다

\section{고 찰}

수하양성 피조개의 밀도별 성장시험기간 중 조사된 해양환

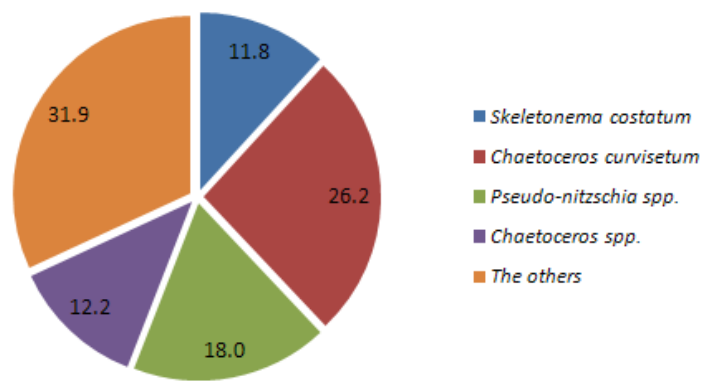

Fig. 12. Ratio of dominant species over 100 numbers per 1 $\mathrm{ml}$ at Namhae area.

경 요인 중에서 패류의 성장에 영향을 미치는 중요한 환경요인 으로 수온과 먹이생물 (Barber and Blake, 1983; Wildish et al., 1988, Palmer and Williams, 1980; Urban and Langdon, 1984; Whyte, 1987) 을 들 수 있고, 패류양식장의 노화로 인한 저질의 산소 부족으로 발생하는 빈산소 수괴는 패 류의 폐사의 한 원인이라는 보고 (김 등, 2000, 2001) 가 있 다. 본 연구에서는 남해해역의 여름철 수온이 $25.66^{\circ} \mathrm{C}$ 로 여수 해역의 $23.85^{\circ} \mathrm{C}$ 보다 높게 유지되었고, 먹이생물인 식물성플랑 크톤의 출현종수와 우점종은 유사하였으나, 출현량은 여수해역 이 남해해역의 $55.89 \%$ 에 불과하여 피조개의 성장에 제한요인 으로 작용하였을 것으로 사료되었다. 한편 $\mathrm{DO}$ 는 $7.02 \mathrm{mg} / \mathrm{L}$ 이상으로 수온 $15{ }^{\circ} \mathrm{C}$ 에서 피조개의 $\mathrm{LC}_{50}$ 은 $1.98 \mathrm{mg} / \mathrm{L}$ 였고, 수온 $25^{\circ} \mathrm{C}$ 에서 피조개의 $\mathrm{LC}_{50}$ 은 $3.89 \mathrm{mg} / \mathrm{L}$ 였다 (Shin et $a l ., 2008)$ 는 보고로 미루어 본 밀도 실험구별 성장차이에 영 향을 미치지는 않았다고 사료된다. 한편, 밀도별 수하양성 시 험 기간 중의 수온은 $16.22-25.66^{\circ} \mathrm{C}$ 로 나타났는데 이에 대해

Table 1. The results of water quality during density rearing experiments of Scapharca broughtonii by areas.

\begin{tabular}{|c|c|c|c|c|c|c|c|c|c|}
\hline Station & $\begin{array}{c}\text { Measurement } \\
\text { date }\end{array}$ & $\begin{array}{c}\text { Water } \\
\text { temperature }\left({ }^{\circ} \mathrm{C}\right)\end{array}$ & & Salinity(\%o) & & pH & & $\mathrm{DO}(\mathrm{mg} / \mathrm{L})$ & \\
\hline \multirow{6}{*}{ Yeosu } & 5.26 & 16.22 & & 32.25 & \multirow{4}{*}{33.32} & 8.17 & \multirow{4}{*}{8.22} & \multicolumn{2}{|l|}{9.56} \\
\hline & 6.29 & 18.92 & & 32.87 & & 8.13 & & \multicolumn{2}{|l|}{8.56} \\
\hline & 7. 26 & 23.50 & 16.22 & 32.55 & & 8.25 & & \multicolumn{2}{|l|}{8.17} \\
\hline & 8. 24 & 22.19 & 23.85 & 32.80 & & 8.19 & & \multicolumn{2}{|l|}{8.91} \\
\hline & 10.01 & 23.85 & & 31.80 & & 8.16 & & \multicolumn{2}{|l|}{7.02} \\
\hline & 10. 29 & 16.95 & & 33.48 & & 8.39 & & \multicolumn{2}{|l|}{8.49} \\
\hline \multirow{6}{*}{ Namhae } & 5.25 & 16.71 & & 31.96 & & 8.10 & & 8.81 & \\
\hline & 6.25 & 18.67 & \multirow{3}{*}{$\begin{array}{c}16.71 \\
\sim \\
25.66 \\
\end{array}$} & 31.07 & & 8.27 & & \multicolumn{2}{|l|}{8.40} \\
\hline & 7. 27 & 23.79 & & 31.28 & 32.63 & 8.39 & 8.33 & 8.79 & 8.80 \\
\hline & 8.25 & 25.66 & & 30.07 & & 8.41 & & \multicolumn{2}{|l|}{9.65} \\
\hline & 9. 30 & 22.65 & & 31.49 & & 8.33 & & \multicolumn{2}{|l|}{8.63} \\
\hline & 10. 28 & 17.29 & & 32.99 & & 8.45 & & \multicolumn{2}{|l|}{8.52} \\
\hline
\end{tabular}


A Study on Survival and Growth of Ark shell, Scapharca broughtonii with differential density during hanging culture

Choe (1972) 는 피조개 성장에 알맞은 시기는 6월에서 12월 로 보고와 유사한 결과를 보였다. 본 연구에서 각고의 성장은 적은 반면에 육중량의 증가는 많았다. 이는 실험에 사용한 피 조개가 중형패로 각고 성장보다 육중의 증가가 많은 시기였기 때문이라 생각한다. 다른 환경요인인 염분과 용존산소량은 수 산용수1급 범위에 속하는 양호한 수질상태를 보였다.

여수해역의 수하양성 피조개의 밀도별 각고의 성장은 10 마 리구가 $5.21 \mathrm{~mm}$ 로 가장 양호하였고, 그다음은 밀도가 높을수 록 성장이 낮아졌다. 10-20마리구는 30-40마리구와 각장 성 장의 차이를 보였다. 이런 현상은 평균 전중량의 변화에서도 유사하게 나타났는데 10 마리구와 20 마리구는 비슷한 성장을 보인데 비하여 30 마리구와 40 마리구와 뚜렷한 성장 차이를 나 타내어 여수해역에서는 밀도별 피조개의 각장과 전중량은 $10-20$ 마리구의 성장이 양호한 반면 30-40마리구의 성장은 지 체되어, 수하양성 중 피조개의 성장은 밀도가 높아질수록 성장 률이 낮아지는 역 상관관계 (Widman and Rhodes, 1991; Mroczka et al., 1996) 를 보였다.

한편, 남해해역의 밀도별 피조개 성장도 여수해역과 같이 역 상관관계를 보였으나, 밀도별 각장 성장은 10 마리구가 4.55 $\mathrm{mm}$ 로 가장 양호한 결과를 보였으나, 20-40마리구의 평균각 장의 성장은 밀도에 따른 차이가 거의 없었다. 반면, 밀도별 전 중량은 10-20마리구가 30-40마리구와 차이를 보였으나 밀도 에 따른 전중량은 각장의 경유와 유사하게 차이가 크지 않아 밀도가 높을수록 성장이 낮아지는 역 상관관계가 남해해역은 여수해역에 비하여의 약하게 나타났다. 이런 현상은 피조개 성 장에 있어 밀도의존성의 강약은 해역의 양성 환경 중 수온과 먹이생물인 식물플랑크톤의 양적 차이에 기인하였다고 사료되 었다.

Broom and Mason (1978) 은 가리비의 한 종에 대한 연 구에서 성장은 수온과 식물 플랑크톤의 양에 상호 영향을 받았 다고 보고하였으며, 패류의 성장에 영향을 주는 요인으로 먹이 생물인 식물플랑크톤과 수온 (ANDI ASSIR, 1993; Urban and Langdon, 1984; MacDonald Thompson, 1985) 이라 는 여러 보고와 같은 결과를 보였다.

이런 환경요인은 해역별 피조개의 생존율에도 영향을 주어 여수해역의 밀도별 피조개 생존율은 $68-87 \%$ 인데 비하여 남해 해역은 $91-100 \%$ 로 높게 나타나는 원인이 된 것으로 사료되었 다. 먹이생물인 식물성플랑크톤의 질적인 문제, 즉 출현종과 출현종수도 중요하다는 보고 (YSFRI, 1991; Peirson, 1983) 도 있으나 이번 연구에서는 밀도 실험을 한 여수 및 남해해역 은 지리적으로 가까이 인접한 해역의 특성으로 인하여 식물픙 랑크톤의 분석 결과 (Fig. 11-12) 와 같이 출현종과 출현종수 및 우점종 등이 매우 유사하게 나타나 먹이생물의 질적 차이가 피조개의 성장에 있어 해역별 사육밀도와 상관관계에 영향을
미치는 요인으로 작용하지는 못하였다고 볼 수 있다.

이번 연구에서 수하양성 피조개의 적정 사육밀도는 여수 및 남해해역 모두 20 마리/0.12 $\mathrm{m}^{2}$ 로 나타났는데, 이를 $1 \mathrm{~m}^{2}$ 로 환산하여 보면, 166 마리 $1 \mathrm{~m}^{2}$ 가 된다. 해만가리비의 경우 적 정 사육밀도를 80-100마리 $/ \mathrm{m}^{2}$ (YSFRI, 1991), 211마리/ $\mathrm{m}^{2}$ (Oh et al., 2000) 와 250마리/m² (Duggan, 1973; Widman and Rhodes, 1991) 와 비교하여 다소 낮은 밀도를 보였으나 이는 실험 종료시 전중량이 해만가리비의 경우 $53 \mathrm{~g}(\mathrm{Oh}$ et $a l ., 2000)$ 이었으나 피조개는 $75 \mathrm{~g}$ 인 것을 감안하면 피조개 수하양성 밀도는 20 마리 $/ 0.12 \mathrm{~m} 2$ 가 적당한 것으로 사료되 었다.

\section{요 약}

여수 횡간도 지역에서 밀도별 피조개 각장 과 전중량의 성 장은 밀도와 역 상관관계를 보였다. 밀도별 각장 평균성장은 10 마리구가 $5.21 \mathrm{~mm}$ 로 가장 양호하였으며 밀도가 높을수록 각장 성장은 낮아졌다. 밀도별 전중량의 증가도 같은 결과를 보여 전반적으로 $10-20$ 마리구의 평균각장 및 평균 전중량의 증가가 30-40마리구에 비하여 양호하게 나타났다.

남해해역에서 밀도별 피조개 각장과 전중량의 성장도 밀도 와 역 상관관계를 보였으나 여수해역보다 약한 역 상관관계를 보였다. 밀도별 각장 평균성장은 10 마리구가 $4.55 \mathrm{~mm}$ 로 가 장 양호한 결과를 보였으나, $20-40$ 마리구의 밀도별 평균각장 의 성장은 $3.11,3.36,3.27 \mathrm{~mm}$ 로 비슷하게 나타났다. 반면 에 밀도별 전중량의 증가는 10-20마리구가 30-40마리구보다 많았다. 결론적으로 피조개의 수하양성시 양성밀도는 20 마리 $10.12 \mathrm{~m}^{2}\left(166\right.$ 마리 $\left./ 1 \mathrm{~m}^{2}\right)$ 가 적당하다고 사료되었다.

여수해역에서 피조개의 생존율은 밀도별로 각각 $68 \%-87 \%$, 로 밀도의존적 결과를 보였으나, 먹이생물인 식물플랑크톤이 풍부한 남해해역의 생존율은 $91 \%-100 \%$ 로 월등히 양호한 결 과를 보였는데, 이는 여수해역의 식물플랑크톤의 양이 남해해 역의 $55.89 \%$ 에 불과하였기 때문이라 사료된다.

수하 양성 해역별의 수온범위는 $16.22-25.66^{\circ} \mathrm{C}$ 였고, 염분은 30.07-33.48였으며, $\mathrm{pH}$ 는 8.10-8.45범위였다. 그리고 용존산 소 $(\mathrm{DO})$ 는 4.49-9.65 mg/L 였다.

\section{사 사}

본 연구는 국립수산과학원 남서해연구소 2010년도 수산시 험연구사업비로 수행되었습니다.

\section{REFERENCES}

Andi, A., (1993) Differential growth characteristics of sea scallop, Placopecten magellanicus (Gmelin, 1791) in suspended culture. MS Thesis (Biology). Acadia Uni- 
versity, 95pp.

Barber, B. J. and N. J. Blake, (1983) Growth and reproduction of the bay scallop, Argopecten irradians (L.). J. North W. Atl. Fish. Sci., 5: 103-104.

Broom, M.J. and J. Mason, (1978) Growth and spawning in the pectinid Chlamys opercularis in relation to temperature and phytoplankton concentration. Mar. Biol., 47: 277-285.

Choi, S. D., Kim, Y. S., Woo, C. Y., Lee, Y. H., Jo, J. H., Kim, D. Y., and Choe, K. J., (2000) Growth and survival rate of ark shells, Scapharca broughtoni cultured on hanging and bottom in Kamak Bay. Bullutin of Fisheries science Institute, Yeosu National University, 9: 122-127.

Choe, K. J.(1972). The variations of morphology and blood pigment in the experimental hanging culture of ark shell, Anadara broughtonii Bullutin of Yeo su Fishery Technology College, 6(2): 1-8.

Duggan, W. P., (1973) Growth and survival of the bay scallop, Argopecten irradians, at various locations in the water column and at various densities. Proc. Nat'l. Shellfish. Assoc., 63: 68-71.

Kim, B. Y., Kim, Y., Koo, J. H. and Hue, J. S., (1982) Studies on the hanging culture of Ark shells, Anadara broughtoni SCHRENCK. Bullutin. Fishery Research and Development Agency Vol. 30, pp. 103-110.

Kim, B.H., Shin, Y.K., Park, K.Y., Choi, N.J. and Oh, B.S. (2008) Growth and survival of the spat of Arkshell, Scapharca broughtonii in intermediate culture with different shape of protective net and type of preventive net of spat loss. Korean Journal of Malacology, 24(2): 131-136.

Lee, J.S. and Min, D.J. (2002) A catalogue of molluscan fauna in Korea. Korean Journal of Malacology, 18: 93-217.

MacDonald, B.A. and R.J. Thompson (1985) Influence of temperature and food availability on the ecological energetics of the giant scallop Placopecten magellanicus. I. Growth rates of shell and somatic tissue. Mar. Ecol. Prog. Ser., 25: 279-294.

Mroczka, M., P. Dinwoodie, R. Goldberg, J. Pereira, P. Clark, S. Stiles, J. Choromanski, D. Schweitzer and N. Balcom (1996) Culture of the bay scallop, Argopecten irradians, within a small-boat marina on Long Island Sound (Connecticut). J. Shellfish. Res. 16(1), 273pp.

Nagagawa, K., Takuya E. and Hiroyuki S. (1999) Examination of intermediate breeding opening time in the cultivation of Scapharca broughtonii . Bullutin of Fukuoka Fisheries marine Technology Res. Center, No. 9: 47-50.

Oh, B. S., Jung, C. G., Yang, M. H. and Kim, S. Y., (2000) Effect of rearing density in culture cage on the growth of the bay scallop, Argopecten irradians. Bulletin of national Fisheries Research and Development Institute, 58: 107-115.

Palmer, R. E. and L. G. Williams (1980) Effect of particle concentration on filtration efficiency of the bay scallop Argopecten irradians and the oyster Crassostrea virginica. Ophelia, 19(2): 163-174.

Peirson, W. M. (1983. Utilization of eight algal species by the bay scallop, Argopecten irradians concentricus (Say). J. Exp. Mar. Biol. Ecol., 68: 1-11.

Shin, Y.K., Kim, B.H., Choi, N.J., Jung, C,G. and Park, M,W. (2008) Influence of temperature, salinity and hypoxia on survival and metabolic rate in the Ark shell, Korean Journal of Malacology, 24(1): 59-65.

Song, H. I., Park, K. J., Cho, Y. R. and Park, Y. J. (2002) Density dependent growth of ark shell, Scapharca satowi in the west coast of Korea. J. of Aquaculture, 15(3): 145-155.

Urban, E .R. and C. J. Langdon (1984) Reduction in cost of diets for the American oyster, Crassostrea (Gmelin), by the use of non- algae supplements. Aquaculture, 38: 277-291.

Widman, J. C. and E. W. Rhodes (1991) Nursery culture of the bay scallop, Argopecten irradians irradians, in suspended mesh nets. Aquaculture, 99: 257-267.

Wildish, D .J., A. J. Wilson, W. Young-Lai, A. M. DeCoste, D. E. Aiken and J. D. Martin (1988) Biological and economic feasibility of four grow-out methods for the culture of giant scallops in the Bay of Fundy. Can. Tech. Rep. Fish. Aquat. Sci., 1658: 1-22.

Whyte, John N. C. (1987) Biochemical composition and energy, content of six species of phytoplankton used in mariculture of bivalves. Aquaculture, 60: 231-241.

Yoo, S.K. and Park, K. Y. (1978) Biological studies on ark shell culture, 2. growth of the Anadara brougtonii. Bull. Nat. Fish. Univ. Busan, 18(1,2): 83-88.

YSFRI (Yellow Sea Fisheries Research Institute) (1991) Training manual on breeding and culture of scallop and sea cucumber in China. Regional Sea Farming Development and Demonstration Project (RAS/90/002). 84 pp.

국립수산과학원 (2012) 피조개 양식산업 복원화 연구, 국립수산 과학원 사업보고서, $147 \mathrm{pp}$.

김숙양, 전상호, 이영식, 이용화, 김병만 (2011) 가막만 빈산소 발생시 해수·퇴적물 곁계면에서 인산염 플럭스 특성, 한국환 경과학회지, 20(9): 1069-1078.

김숙양, 이용화, 김영숙, 심정희, 예미주, 전지원, 황재란, 전상호 (2012) 2010년 진해만 빈산소수괴 발생시 환경변화 특성, 한국환경과학회지, 6(2): 1069-1078.

농림수산식품부 (2012) 농림수산통계연보. 298pp. 